\title{
Buckling up in Singapore: residency and other risk factors for seatbelt non- compliance - a cross-sectional study based on trauma registry data
}

Ting Hway Wong ${ }^{1,4^{*}}$, Gek Hsiang Lim², Khuan Yew Chow ${ }^{2}$, Trauma Coordinators and Trauma Service Representatives, Nyi Nyi Zaw ${ }^{3}$, Hai Van Nguyen ${ }^{4}$, Hoong Chor Chin ${ }^{5}$ and Marcus Eng Hock Ong ${ }^{3,4}$

\begin{abstract}
Background: Seatbelt non-compliance is a problem in middle income countries, and little is known about seatbelt compliance in populations with a high proportion of non-residents. This study analyses the profile of seatbelt noncompliance in Singapore based on trauma registry data from five of the six public hospitals.

Methods: This is a cross-sectional study of seatbelt compliance of patients aged over 18 years, attending the emergency departments of five public hospitals in Singapore after road collisions from 2011-2014. Seatbelt data was obtained from paramedic and patient history.

Results: There were 4,576 patients studied. Most were Singapore citizens (83.4 \%) or permanent residents (2.4\%), with the largest non-resident groups from Malaysia, India, and China. Overall seatbelt compliance was $82.1 \%$. On univariate analysis, seatbelt compliance was higher in older patients (OR 1.02, $95 \% \mathrm{Cl} 1.001-1.021, p<0.0001)$; drivers, followed by front passengers (OR 0.65, $95 \% \mathrm{Cl} 0.51-0.83, p<0.0001)$, were more compliant than rear passengers (OR 0.08, 0.06-0.09, $p<0.0001$ ); occupants of larger vehicle types (buses, heavy transport vehicles, minibuses and vans) were more non-compliant compared to occupants of private cars and taxis. Morning peak travel (0700 h-0900 h) and being a non-resident were other risk factors for non-compliance.

On multivariable analysis, older age (OR 1.01, $95 \% \mathrm{Cl} 1.001-1.014, p=0.03)$ was associated with compliance, while non-residents from China (OR 0.43, $95 \% \mathrm{Cl} 0.18-0.99, p=0.05$ ), seat position (front passenger compared to driver,

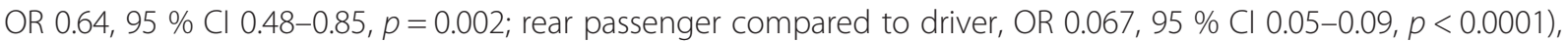
vehicle type (bus compared to car, OR 0.04, $95 \%$ Cl 0.017-0.11, $p<0.0001$, van compared to car, OR 0.55, $95 \% \mathrm{Cl}$ $0.36-0.83, p=0.004$ ), and travel at morning peak periods were independent predictors of seatbelt non-compliance. When the sub-group of drivers was analysed, only vehicle type was a significant predictor of seatbelt compliance, with bus drivers least likely to be compliant to seatbelts (multivariable analysis, OR 0.057 compared to cars, $95 \% \mathrm{Cl}$ $0.019-0.18, p<0.0001)$.

Conclusions: While overall seatbelt compliance in our study is high, efforts can be made to increase compliance for morning rush hour passengers, rear seat passengers, and occupants of buses, heavy transport vehicles, and vans or pickups.
\end{abstract}

Keywords: Seatbelt compliance, Immigrant behaviour, Singapore, Asia, Trauma registry

\footnotetext{
* Correspondence: wong.ting.hway@singhealth.com.sg

'Department of General Surgery, Singapore General Hospital, Outram Road, Singapore 169608, Singapore

${ }^{4}$ Duke-National University of Singapore Graduate Medical School, 8 College

Rd, Singapore 169857, Singapore

Full list of author information is available at the end of the article
} 


\section{Background}

Seatbelt non-compliance is a problem in middle income countries, with seatbelt use lagging behind vehicle ownership trends $[1,2]$. Seatbelt compliance rates can be estimated by observational studies, self-report questionnaires, or from on-scene information for motor vehicle crash victims [3-7]. Understanding the profile of vehicle users who are non-compliant with seatbelt regulations has important implications for targeted safety campaigns and educational measures.

Singapore is a city-state with a land area of $719.1 \mathrm{~km}^{2}$ and a population of 5.5 million. The population is multiracial with the major ethnic groups being Chinese, Malay, and Indian, and with non-residents comprising almost $30 \%$ of the population [8]. Seatbelt legislation for drivers and front passengers was passed in Singapore in 1973, and for rear passengers in 1993. As such, seatbelt compliance and installation of seat belts has been required in both the front and rear of cars and taxis as of 1993. Rear belts in private buses, mini-buses, and vans are mandatory in vehicles registered on or after April 2009 [9], and it is mandatory to use them where available. While there have been studies of seatbelt compliance in the region showing relatively low compliance with seatbelts $[10$, $11]$, especially for rear seat passengers [12], there have been no studies of seatbelt compliance in Singapore. Studies from the region have been observational or survey-based [10-20]. Pure observational studies without direct interview with the occupants cannot differentiate non-residents from residents, while self-report questionnaires may be difficult to administer to certain social and linguistic groups, including the transient migrant worker and non-resident population.

Motor vehicle crashes are the second highest cause of injury in Singapore after falls [21]. Among the motor vehicle crash victims, injuries to motor vehicle occupants are the second most common, after motorcyclist injuries. The goal of our study was to determine the prevalence and analyse the associated risk factors of patients who are non-compliant with seatbelts, with a view to target high-risk groups in future. Of particular interest in our setting of a high-non-resident population was whether residency status and country of origin affected seatbelt compliance.

\section{Methods}

\section{Data source and data collection}

Seatbelt compliance is one of the optional data collection fields collected in five of the six public hospitals participating in the Singapore National Trauma Registry (NTR), which was started in 2011 [21]. Data collection for the NTR is performed by teams of trained trauma data coordinators based at each public hospital, with data cleaning, data completeness, data quality, and inter- rater audits performed annually; inclusion criteria and data collection details can be found in the annual report and previous publications $[21,22]$. There is a single national emergency ambulance number and all hospitals that receive Singapore Civil Defence Force ambulances (i.e. all public hospitals) provide data for the NTR [23].

De-identified data from five of the six adult public hospitals contributing data to the NTR were pooled. Three hospitals collected seatbelt compliance data from 2011, one started in 2012, and one started in 2013. The remaining public hospital, which has the lowest patient volume of the six hospitals, did not collect data for the optional field on seatbelt compliance. Two of the hospitals routinely collect seatbelt compliance data for all patients who present to the hospital, while three collected data only for moderately and severely injured patients (injury severity score of 9 and above). Seatbelt data was primarily entered based on paramedic and patient history, with a minority of cases being inferred from the mechanism of injury (e.g. patient found unbelted on the floor of the vehicle without vehicle rollover). Demographic data, use of seatbelt, position in vehicle (driver, front passenger, or rear passenger), vehicle type (private car, taxi, bus, mini-bus, van/pick-up truck, or heavy goods vehicle), alcohol (documented clinically and/or confirmed on toxicology), pregnancy status where documented, date and time of injury presentation, and whether the injury was work-related were extracted from the registry. The de-identified datasets from the hospitals were merged with the National Trauma Registry data to obtain the demographic information of the subjects. The merged dataset was analysed by a statistician in the National Registry of Diseases Office (NRDO) that manages NTR, aggregated numbers were then released to the research/ study team for further interpretation.

\section{Study population}

Vehicle occupants aged 18 and above attending the emergency departments of participating institutions after a motor vehicle collision were included in the study. Patients without known seatbelt information were excluded from analysis.

As the availability of rear seatbelts in heavy transport vehicles, vans, trucks, mini-buses, and buses depends on the date of vehicle registration (only mandatory for vehicles registered after the law was passed in 2009) [9], patients who were rear passengers in these vehicles were excluded from our analysis, as it was not possible to distinguish whether the lack of compliance in these patients was due to the lack of availability of seatbelts or patients' behaviour.

\section{Study design}

This was a cross-sectional study based on prospectively collected data from January 2011 to December 2014, of 
patients aged over 18 years, attending the emergency departments of five public hospitals in Singapore after road collisions. Seatbelt data was obtained from paramedic and patient history during the admission for the incident.

The associations between seatbelt compliance and age, gender, race, residency status, position in vehicle, vehicle type, alcohol, pregnancy, time of day, weekday versus weekend, and whether injury was work-related were examined. In view of the different inclusion criteria for the various contributing hospitals, the hospital was included as a covariate in the multivariable model.

\section{Outcome measure}

The outcome of interest was seatbelt compliance.

\section{Statistical analysis}

Patient characteristics at baseline were summarised by mean (standard deviation), median (inter-quartile range), or frequency (\%) as appropriate. Chi-square tests and Fisher's exact test were performed to evaluate associations between the outcomes of interest and other categorical predictors of interest, while t-test was used for age, after testing for normality and homogeneity of variance. Univariate logistic regression was used to analyse association with seatbelt compliance. Multivariable analysis was performed for factors that were significant at the $10 \%$ level in the univariate analysis. Factors that were not significant on univariate analysis, but known to be risk factors in the literature, were included in the multivariable model. Sensitivity analysis excluding these variables was performed. Patients with missing seatbelt information were excluded from the main model. Stata 13.0 was used.

\section{Results}

\section{Descriptive analysis}

From 2011 to 2014, there were 4,911 patients with documented seatbelt status in the five institutions. There were 3996 vehicle occupants whose seatbelt status was not available. Of the patients with documented seatbelt status, the following patients were excluded: 96 patients coded as rear seat passengers in a bus, 19 patients coded as rear seat passengers in a mini-bus (defined as fewer than 20 passengers), 86 patients coded as rear seat passengers in a van or pickup, and 134 patients coded as rear passengers in heavy goods vehicles. Seatbelt compliance was only $6.9 \%$ in these excluded patients.

Of the remaining 4,576 patients studied, the median age was 40.7 years, with males accounting for nearly twothirds of the sample $(64.4 \%)$. The majority were Singapore citizens $(83.4 \%)$ or permanent residents $(2.4 \%)$, with the largest non-resident groups coming from Malaysia,
India, and China. Overall seatbelt compliance in the study population was $82.1 \%$. Summary statistics are presented in Table 1.

\section{Univariate analysis}

Seatbelt compliance was higher in older patients; drivers, followed by front passengers, were more compliant than rear passengers, while occupants of larger vehicle types were more non-compliant compared to occupants of private cars (Table 2).

Table 1 Summary Statistics

\begin{tabular}{|c|c|c|}
\hline & & $\begin{array}{l}\text { Number (\%)/ } \\
\text { Mean (SD) }\end{array}$ \\
\hline & Seatbelt Compliance & $3759(82.1)$ \\
\hline \multicolumn{3}{|l|}{ Demographics } \\
\hline & Age & 40.7 (SD 14.1) \\
\hline & Males & $2949(64.4)$ \\
\hline \multirow[t]{5}{*}{ Country of Residence } & Singapore & $3928(85.8)$ \\
\hline & Malaysia & $122(2.7)$ \\
\hline & India & $51(1.1)$ \\
\hline & China & $45(1.0)$ \\
\hline & Other Nationalities & $430(9.4)$ \\
\hline \multicolumn{3}{|l|}{ Vehicle Type } \\
\hline & $\begin{array}{l}\text { Bus (capacity of } 20 \text { or } \\
\text { more passengers) }\end{array}$ & $23(0.5)$ \\
\hline & Heavy Transport Vehicle & $282(6.2)$ \\
\hline & $\begin{array}{l}\text { Minibus (less than } 20 \\
\text { passengers) }\end{array}$ & $23(0.5)$ \\
\hline & Private Car & $2706(59.1)$ \\
\hline & Taxi & $890(19.4)$ \\
\hline & Van or Pickup & $248(5.4)$ \\
\hline & Unknown & $404(8.8)$ \\
\hline \multicolumn{3}{|l|}{ Seat Position } \\
\hline & Driver & $2853(62.3)$ \\
\hline & Front Passenger & $836(18.3)$ \\
\hline & Rear Passenger & $798(17.4)$ \\
\hline & Unknown & $89(1.9)$ \\
\hline \multicolumn{3}{|c|}{ Other Associated Risk Factors } \\
\hline & Alcohol Use & $73(1.6)$ \\
\hline & Pregnancy & 3 \\
\hline & Work-related & $81(1.8)$ \\
\hline \multirow[t]{4}{*}{ Time of Arrival } & 0700-0959 h & $406(8.9)$ \\
\hline & 1000-1659 h & $1647(36.0)$ \\
\hline & 1700-1959 h & $744(16.3)$ \\
\hline & 2000-0659 h & $1779(38.9)$ \\
\hline Day of Arrival & Weekdays & 3261 (71.3) \\
\hline
\end{tabular}


Table 2 Factors affecting Seatbelt Compliance

\begin{tabular}{|c|c|c|c|c|c|c|c|}
\hline & & Seatbelt Compliance & $\begin{array}{l}\text { Non-compliant [Number } \\
(\%) / \text { Mean (SD)] }\end{array}$ & $\begin{array}{l}\text { Compliant [Number } \\
(\%) / \text { Mean (SD)] }\end{array}$ & $\begin{array}{l}\text { Odds } \\
\text { Ratio }\end{array}$ & $95 \% \mathrm{Cl}$ & $P$ \\
\hline \multirow{3}{*}{\multicolumn{2}{|c|}{ Demographics }} & Age & 38.3 (SD 15.0) & 41.2 (SD13.8) & 1.02 & $1.001-1.021$ & $<0.0001$ \\
\hline & & Males & $406(13.67)$ & $2563(86.33)$ & 2.17 & $1.86-2.53$ & $<0.0001$ \\
\hline & & Females & $411(25.58)$ & $1196(74.42)$ & 1 (Ref) & & \\
\hline \multirow{5}{*}{\multicolumn{2}{|c|}{ Country of Residence }} & Singapore & 649 (16.52) & $3279(83.48)$ & 1 (Ref) & & $<0.0001$ \\
\hline & & Malaysia & $14(11.48)$ & $108(88.52)$ & 1.53 & $0.87-2.68$ & \\
\hline & & India & $7(13.73)$ & $44(86.27)$ & 1.24 & $0.56-2.77$ & \\
\hline & & China & $13(28.89)$ & $32(71.11)$ & 0.49 & $0.25-0.93$ & \\
\hline & & Other Nationalities & $134(31.16)$ & $296(68.84)$ & 0.44 & $0.35-0.55$ & \\
\hline \multirow{7}{*}{\multicolumn{2}{|c|}{ Vehicle Type }} & $\begin{array}{l}\text { Bus (capacity of } 20 \text { or more } \\
\text { passengers) }\end{array}$ & $15(65.22)$ & $8(34.78)$ & 0.09 & $0.04-0.22$ & $<0.0001$ \\
\hline & & Heavy Transport Vehicle & $30(10.64)$ & $252(89.36)$ & 1.43 & $0.96-2.12$ & \\
\hline & & $\begin{array}{l}\text { Minibus (less than } 20 \\
\text { passengers) }\end{array}$ & $4(17.39)$ & $19(82.61)$ & 0.81 & $0.27-2.38$ & \\
\hline & & Private Car & 393 (14.52) & $2313(85.48)$ & 1 (Ref) & & \\
\hline & & Taxi & $231(25.96)$ & $659(74.04)$ & 0.48 & $0.40-0.58$ & \\
\hline & & Van or Pickup & $33(13.31)$ & $215(86.69)$ & 1.11 & $0.76-1.62$ & \\
\hline & & Unknown vehicle & $111(27.48)$ & $293(72.52)$ & 0.45 & $0.35-0.57$ & \\
\hline \multirow{4}{*}{\multicolumn{2}{|c|}{ Seat Position }} & Driver & $245(8.59)$ & $2608(91.41)$ & 1 (Ref) & & $<0.0001$ \\
\hline & & Front Passenger & $105(12.56)$ & 731 (87.44) & 0.65 & $0.51-0.83$ & \\
\hline & & Rear Passenger & $441(55.26)$ & $357(44.74)$ & 0.08 & $0.06-0.09$ & \\
\hline & & Unknown position & $26(29.21)$ & $63(70.79)$ & 0.23 & $0.14-0.37$ & \\
\hline \multirow[t]{6}{*}{$\begin{array}{l}\text { Other Associated Risk } \\
\text { Factors }\end{array}$} & \multirow[t]{2}{*}{$\begin{array}{l}\text { Alcohol } \\
\text { use }\end{array}$} & $\begin{array}{l}\text { Alcohol Use (clinical or } \\
\text { toxicological) }\end{array}$ & $13(17.81)$ & $60(82.19)$ & 1.002 & $0.55-1.83$ & 0.994 \\
\hline & & No alcohol use & $777(17.84)$ & $3578(82.16)$ & 1 (ref) & & \\
\hline & \multirow[t]{2}{*}{ Pregnancy } & Pregnant & $2(66.67)$ & $1(33.33)$ & 0.17 & $0.02-1.85$ & 0.202 \\
\hline & & $\begin{array}{l}\text { Not pregnant or status } \\
\text { unknown, female aged } \\
\text { below } 50\end{array}$ & 209 (18.54) & 918 (81.46) & 1 (ref) & & \\
\hline & \multirow{2}{*}{$\begin{array}{l}\text { Work- } \\
\text { related }\end{array}$} & Work-related & $7(8.64)$ & $74(91.36)$ & 1 (ref) & & 0.029 \\
\hline & & Not Work-related & $810(18.04)$ & $3681(81.96)$ & 2.33 & $1.07-5.07$ & \\
\hline \multirow[t]{6}{*}{ Time of Arrival } & & 0700-0959 h & $92(22.66)$ & $314(77.34)$ & 1 (ref) & & 0.040 \\
\hline & & 1000-1659 h & $300(18.21)$ & $1347(81.79)$ & 1.32 & $1.01-1.71$ & \\
\hline & & 1700-1959 h & $126(16.94)$ & $618(83.06)$ & 1.44 & $1.06-1.94$ & \\
\hline & & 2000-0659 h & $299(16.81)$ & $1480(83.19)$ & 1.45 & $1.11-1.89$ & \\
\hline & & Weekdays & $566(17.36)$ & $2695(82.64)$ & 1 (ref) & & 0.167 \\
\hline & & Weekends & 251 (19.09) & $1064(80.91)$ & 0.89 & $0.76-1.05$ & \\
\hline
\end{tabular}

Females were more likely to be non-compliant. Nonresidents were also more likely to be non-compliant. Non-resident groups were further assessed by individual nationalities, and divided into nationalities comprising more than $1 \%$ of the study population (citizens of Malaysia, India, and China), with the remaining nationalities grouped together ("others"). While work-related injuries were not significant on overall univariate analysis, a closer inspection of the subgroup of drivers who were non-compliant showed that they were mostly work-related large vehicle drivers.

While there was no difference between weekday and weekend compliance, morning rush hour crashes yielded more patients who were un-belted. The timebands were chosen to reflect morning and evening office commute peak hour timings, daytime non-peak and night-time non-peak. Histograms of the compliance levels across the 24-h time-period showed that 
compliance levels were fairly consistent within each of the four time-bands.

Patients from hospitals where data on seatbelt compliance was also collected for patients with only minor injuries were more likely to have worn a seatbelt, which is consistent with the protective effect of seatbelts.

\section{Multivariable analysis}

Younger age, seat position, vehicle type, and travel at morning peak periods were independent predictors of seatbelt non-compliance (Table 3). The only factor significant on univariate analysis, but not multivariable analysis, was gender. As the number of pregnant women in the study was low and not significant on univariate analysis, this factor was omitted from multivariable analysis.
Sensitivity analyses included: exclusion of all factors that were not significant on univariate analysis, re-categorisation of non-citizen permanent residents as non-residents, and inclusion of patients with missing vehicle type and seat position information in the multivariable models. These models yielded similar results.

\section{Sub-group analysis of drivers}

We further conducted a sub-group analysis of drivers (Table 4). Overall compliance was high, with $91.4 \%$ of the 2,853 drivers wearing seatbelts. On univariate analysis, only vehicle type $(p<0.0001)$ and non-resident status (2360/2580 residents compliant, compared to $130 / 152$, $P=0.01)$ were significant. However, when non-residents were grouped by citizenship (Malaysia, China, India and others), the compliance rate for drivers for these three

Table 3 Multivariable Logistic Regression - Likelihood of Seatbelt Compliance

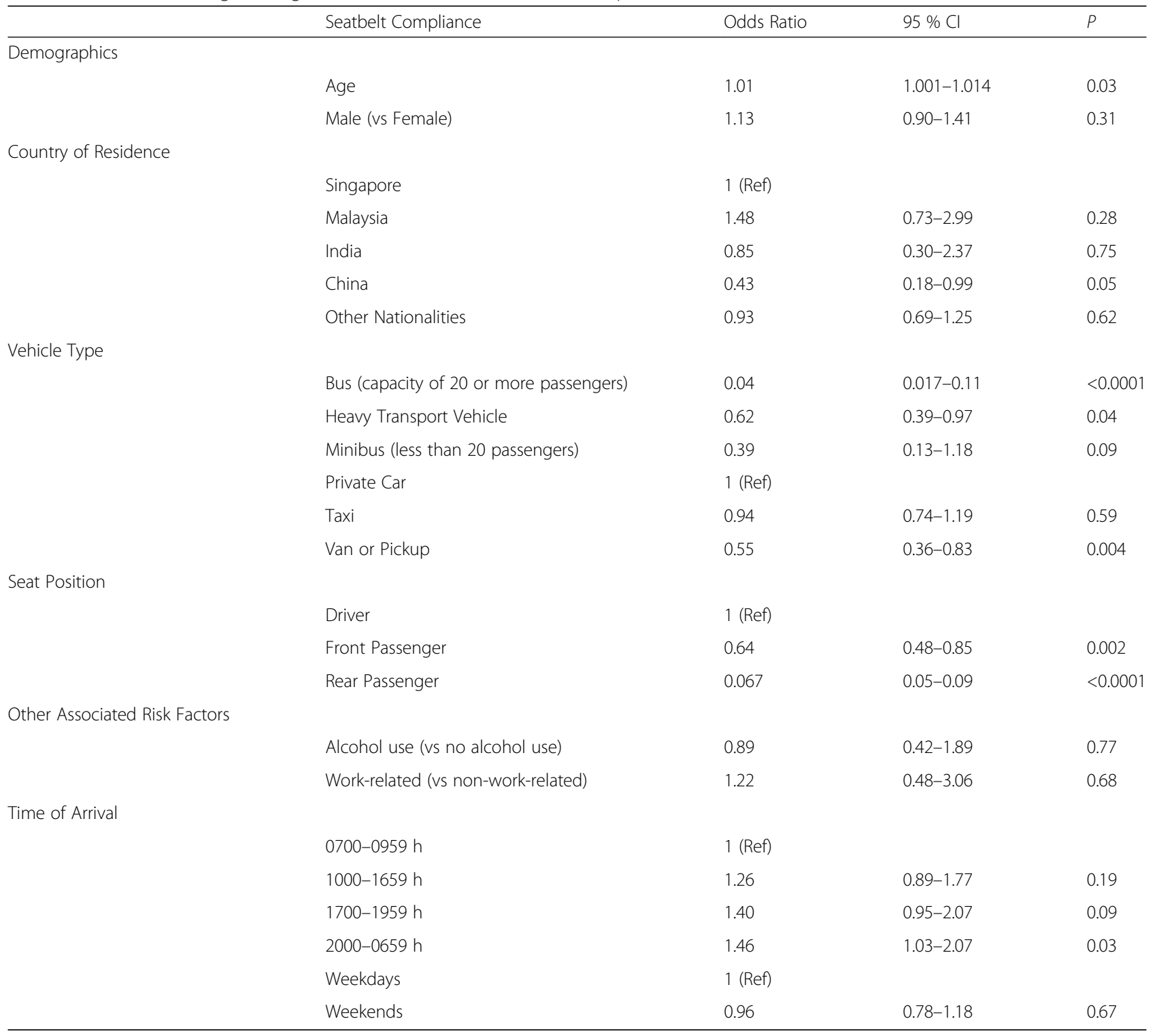


Table 4 Seatbelt Compliance of Drivers

\begin{tabular}{|c|c|c|c|c|c|c|}
\hline & Seatbelt Compliance & $\begin{array}{l}\text { Non-compliant [Number (\%)/ } \\
\text { Mean (SD)] }\end{array}$ & $\begin{array}{l}\text { Compliant [Number (\%)/ } \\
\text { Mean (SD)] }\end{array}$ & OR & $95 \% \mathrm{Cl}$ & $P$ \\
\hline \multirow[t]{3}{*}{ Demographics } & Age & 40.5 (SD 13.9) & 42.2 (SD 13.2) & 1.01 & $0.99-1.02$ & 0.06 \\
\hline & Males & $209(8.94)$ & $2129(91.06)$ & 0.77 & $0.53-1.11$ & 0.15 \\
\hline & Females & $36(6.99)$ & $479(93.01)$ & 1 (Ref) & & \\
\hline \multirow[t]{5}{*}{ Country of Residence } & Singapore & $220(8.53)$ & $2360(91.47)$ & 1 (Ref) & & 0.06 \\
\hline & Malaysia & $2(3.39)$ & $57(96.61)$ & 2.24 & $0.30-16.62$ & \\
\hline & India & $1(4)$ & $24(96)$ & 2.66 & $0.64-10.96$ & \\
\hline & China & $0(0)$ & $21(100)$ & NA & & \\
\hline & Other Nationalities & $22(13.1)$ & $146(86.9)$ & 0.62 & $0.39-0.99$ & \\
\hline \multirow[t]{6}{*}{ Vehicle Type } & $\begin{array}{l}\text { Bus (capacity of } 20 \text { or } \\
\text { more passengers) }\end{array}$ & $9(52.94)$ & $8(47.06)$ & 0.07 & $0.03-0.19$ & $<0.0001$ \\
\hline & Heavy Transport Vehicle & $20(9.09)$ & $200(90.91)$ & 0.82 & $0.50-1.35$ & \\
\hline & $\begin{array}{l}\text { Minibus (less than } 20 \\
\text { passengers) }\end{array}$ & $2(9.52)$ & $19(90.48)$ & 0.78 & $0.18-3.40$ & \\
\hline & Private Car & $132(7.62)$ & $1601(92.38)$ & 1 (Ref) & & \\
\hline & Taxi & $33(6.61)$ & 466 (93.39) & 1.16 & $0.78-1.72$ & \\
\hline & Van or Pickup & $21(11.35)$ & 164 (88.65) & 0.64 & $0.39-1.05$ & \\
\hline
\end{tabular}

countries was slightly higher than Singapore residents (96.6\% for the 59 drivers from Malaysia, $100 \%$ for the 21 drivers from China, $96.0 \%$ for the 25 drivers from India, compared to $91.5 \%$ for the Singapore resident drivers), with the "other nationalities" contributing to the low nonresident compliance rate.

On multivariable analysis, compared to car drivers, drivers of buses were 17.4 times more likely to be noncompliant with seatbelts $(p<0.0001)$, drivers of heavy transport vehicles were 1.9 times more likely to be non- compliant with seatbelts $(p=0.03)$, and drivers of vans or pickups 1.7 times more likely to be non-compliant with seatbelts $(p=0.06)$. None of the other factors were significant (Table 5).

\section{Effect of seatbelt compliance on injury severity}

We compared the severity of injuries of those who were not compliant to the severity of those who were compliant, stratified by the key risk factors. The seatbelt-compliant

Table 5 Multivariable Logistic Regression - Likelihood of Seatbelt Compliance, Drivers Only

\begin{tabular}{|c|c|c|c|c|}
\hline & Seatbelt Compliance & Odds Ratio & $95 \% \mathrm{Cl}$ & $P$ \\
\hline \multicolumn{5}{|l|}{ Demographics } \\
\hline & Age & 1.01 & $0.99-1.02$ & 0.39 \\
\hline & Males & 0.95 & $0.63-1.42$ & 0.80 \\
\hline \multicolumn{5}{|c|}{ Country of Residence } \\
\hline & Singapore & 1 (Ref) & & \\
\hline & Malaysia & 1.70 & $0.22-12.92$ & 0.61 \\
\hline & India & 0.77 & $0.09-6.51$ & 0.81 \\
\hline & China & NA & & \\
\hline & Other Nationalities & 1.05 & $0.60-1.85$ & 0.86 \\
\hline \multicolumn{5}{|l|}{ Vehicle Type } \\
\hline & Bus (capacity of 20 or more passengers) & 0.057 & $0.02-0.18$ & $<0.0001$ \\
\hline & Heavy Transport Vehicle & 0.53 & $0.30-0.95$ & 0.03 \\
\hline & Minibus (less than 20 passengers) & 0.83 & $0.19-3.68$ & 0.81 \\
\hline & Private Car & 1 (Ref) & & \\
\hline & Taxi & 1.18 & $0.76-1.83$ & 0.46 \\
\hline & Van or Pickup & 0.60 & $0.35-1.01$ & 0.06 \\
\hline
\end{tabular}


group had less severe injuries. The results are presented in Table 6.

\section{Discussion}

Our study is the first study of risk factors for seatbelt compliance in Singapore using national injury data, and provides insights into the vulnerable groups that could be targeted in our injury prevention strategies. Similar to other studies in the international and regional literature [4-6, 10-13, 24], older occupants and drivers of cars or taxis were more compliant with seatbelts, compared to occupants of buses, minibuses, heavy transport vehicles, vans or pickups. Rear seat passengers were much less likely to be compliant, and this is likely an underestimate since we only included the rear seat passengers of cars and taxis. Morning was the period with the lowest seatbelt compliance, a similar finding to another study in Asia [14].

As driver behaviour is known to affect compliance of the rest of the vehicle occupants [14], and as some studies only looked at driver behaviour [5, 10, 13, 15, 25], our subgroup analysis of drivers yielded some additional insights. There were overall low compliance rates among drivers of buses, mini-buses, heavy goods vehicles, and vans or pickups, similar to a recent study in Thailand [10]. The numbers of some of these categories (buses, mini-buses) in our study were low. However, as these would be professional drivers, who spend a lot of time on the road, they should still be a target for seatbelt compliance. Similar efforts should be made for drivers of heavy goods vehicles and vans or pickups, as they comprise more than $10 \%$ of our study population.

We did not find any effect of alcohol, pregnancy, or gender in our study. It is not standard practice in Singapore to screen for blood toxicology in our hospitals unless requested by the police. Consequently, patients with a positive alcohol status in our registry include those documented clinically to have consumed alcohol (in the history or the physical examination), as well as those with blood alcohol levels requested by the police. Hence, alcohol status includes patients with mild alcohol levels below the legal limit, who might still be compliant with seatbelts. Pregnant patients in some studies have been shown to be less likely to be compliant with seatbelts [26-28], but there were too few pregnant women in our study. Many studies find males more likely to be non-compliant, but we did not find that in our study.

Studies examining immigrant health behaviours vary in their findings, depending on which health behaviour is studied [29, 30]. One interesting finding in our study is how non-Singaporean residents behave in
Singapore. The main non-Singaporean patient groups (Malaysia, India, and China) all displayed higher overall seatbelt compliance than reported in surveys or observational studies conducted in these three countries [11-20]. The number of Singapore permanent residents in our study population was too low to compare permanent residents and non-residents from the same country. While our study numbers are not high, this suggests that living in a high-compliance country does affect behaviour. An alternative explanation is that the immigrant populations in Singapore are different from the vehicle occupants in their countries, for example, more educated, or more safety-conscious.

Overall compliance rate in our dataset (76.8\%) was higher than similar studies using trauma registry data conducted in North America and Europe [4-6], and even higher in drivers (91.4\%). Our study suggests that non-resident drivers from countries other than the three major non-resident countries of origin (Malaysia, China, and India) could be targeted for compliance. Further studies specifically targeting non-resident drivers could be undertaken, for example, surveys in the languages of these other nationalities, and additional information such as reasons for non-compliance could be obtained in these surveys. With regards to the non-drivers, passengers who are non-residents, particularly the nondriver passengers from China, could also be targeted. While the additional healthcare and societal costs of seatbelt non-compliance is beyond the scope of this paper, the significantly higher injury severity scores in the non-compliant patients suggest that these injuries would have incurred a lower societal and healthcare cost if seatbelt compliance were higher in our study population.

One major limitation of our study is that trauma registry data is only collected for patients brought to hospital, and is hence biased towards injured patients who would be less compliant to seatbelts, compared to survey-based or observational studies [31]. This method also depends on fitness of the patient for interview or documentation in the paramedics' notes. A reliable patient history would be biased towards less injured patients. Similarly, paramedic documentation in severely-injured patients would focus on the severity of injuries and timely transfer to hospital, rather than providing information on seatbelt compliance. Another limitation is that patients may feel compelled to over-report their compliance, for example, due to fear of getting less insurance compensation or from prosecution. Nevertheless, given the relatively large number of patients in our study, collected across multiple sites, this is an important source of information to identify potential target groups for seatbelt compliance and injury prevention [32]. 
Table 6 Injury Severity by Seatbelt Compliance

\begin{tabular}{|c|c|c|c|c|}
\hline & Injury Severity Score (ISS) & $\begin{array}{l}\text { Compliant [Number (\%)/ } \\
\text { Mean (SD)] }\end{array}$ & $\begin{array}{l}\text { Non-Compliant [Number (\%)/ } \\
\text { Mean (SD)] }\end{array}$ & $P$ \\
\hline \multirow[t]{3}{*}{ Total Study Population } & ISS $<9$ & $1205(88.54)$ & $156(11.46)$ & $<0.0001$ \\
\hline & ISS 9-15 & $152(80)$ & $38(20)$ & \\
\hline & ISS > 15 & $2402(79.4)$ & $623(20.6)$ & \\
\hline \multicolumn{5}{|l|}{ Demographics } \\
\hline \multicolumn{5}{|l|}{ Age } \\
\hline & ISS $<9$ & 40.2 (SD 13.3) & 36.1 (SD 14.3) & 0.0003 \\
\hline & ISS 9-15 & 45.9 (SD 15.8) & 51.9 (SD 17.3) & 0.04 \\
\hline & ISS > 15 & 41.4 (SD 13.8) & 38.0 (SD 14.6) & $<0.0001$ \\
\hline \multirow[t]{4}{*}{ Male } & & & & $<0.0001$ \\
\hline & $I S S<9$ & $773(92.35)$ & $64(7.65)$ & \\
\hline & ISS 9-15 & $115(85.82)$ & $19(14.18)$ & \\
\hline & ISS > 15 & $1675(83.83)$ & $323(16.17)$ & \\
\hline \multicolumn{5}{|l|}{ Country of Residence } \\
\hline \multirow[t]{4}{*}{ Singapore } & & & & $<0.0001$ \\
\hline & $I S S<9$ & $992(89.53)$ & $116(10.47)$ & \\
\hline & ISS 9-15 & $130(83.87)$ & $25(16.13)$ & \\
\hline & ISS > 15 & $2157(80.94)$ & $508(19.06)$ & \\
\hline \multirow[t]{4}{*}{ Malaysia } & & & & 0.15 \\
\hline & $I S S<9$ & $86(90.53)$ & $9(9.47)$ & \\
\hline & ISS 9-15 & $5(100)$ & $0(0)$ & \\
\hline & ISS > 15 & $17(77.27)$ & $5(22.73)$ & \\
\hline \multirow[t]{4}{*}{ India } & & & & 0.52 \\
\hline & $I S S<9$ & $38(88.37)$ & $5(11.63)$ & \\
\hline & ISS 9-15 & $2(66.67)$ & $1(33.33)$ & \\
\hline & ISS > 15 & $4(80)$ & $1(20)$ & \\
\hline \multirow[t]{4}{*}{ China } & & & & 0.60 \\
\hline & $I S S<9$ & $28(73.68)$ & $10(26.32)$ & \\
\hline & ISS 9-15 & $2(50)$ & $2(50)$ & \\
\hline & ISS > 15 & $2(66.67)$ & $1(33.33)$ & \\
\hline \multirow[t]{4}{*}{ Other Nationalities } & & & & 0.05 \\
\hline & $I S S<9$ & $61(79.22)$ & $16(20.78)$ & \\
\hline & ISS 9-15 & $13(56.52)$ & $10(43.48)$ & \\
\hline & ISS > 15 & $222(67.27)$ & $108(32.73)$ & \\
\hline \multicolumn{5}{|l|}{ Vehicle Type } \\
\hline \multirow[t]{4}{*}{ Bus (capacity of 20 or more passengers) } & & & & 0.20 \\
\hline & $I S S<9$ & $4(57.14)$ & $3(42.86)$ & \\
\hline & ISS 9-15 & $0(0)$ & $3(100)$ & \\
\hline & ISS > 15 & $4(30.77)$ & $9(69.23)$ & \\
\hline \multirow[t]{4}{*}{ Heavy Transport Vehicle } & & & & 0.16 \\
\hline & ISS $<9$ & $139(92.67)$ & $11(7.33)$ & \\
\hline & ISS 9-15 & $18(85.71)$ & $3(14.29)$ & \\
\hline & ISS $>15$ & $95(85.59)$ & $16(14.41)$ & \\
\hline
\end{tabular}


Table 6 Injury Severity by Seatbelt Compliance (Continued)

\begin{tabular}{|c|c|c|c|c|}
\hline \multirow[t]{4}{*}{ Minibus (less than 20 passengers) } & & & & 0.06 \\
\hline & ISS $<9$ & $4(100)$ & $0(0)$ & \\
\hline & ISS 9-15 & $0(0)$ & $1(100)$ & \\
\hline & ISS > 15 & $15(83.33)$ & $3(16.67)$ & \\
\hline \multirow[t]{4}{*}{ Private Car } & & & & $<0.0001$ \\
\hline & ISS $<9$ & 755 (91.18) & $73(8.82)$ & \\
\hline & ISS 9-15 & $93(84.55)$ & $17(15.45)$ & \\
\hline & ISS > 15 & $1465(82.86)$ & $303(17.14)$ & \\
\hline \multirow[t]{4}{*}{ Taxi } & & & & 0.36 \\
\hline & ISS $<9$ & $205(77.07)$ & $61(22.93)$ & \\
\hline & ISS 9-15 & $25(69.44)$ & $11(30.56)$ & \\
\hline & ISS > 15 & $429(72.96)$ & $159(27.04)$ & \\
\hline \multirow[t]{4}{*}{ Van or Pickup } & & & & 0.005 \\
\hline & ISS $<9$ & $73(96.05)$ & $3(3.95)$ & \\
\hline & ISS 9-15 & $16(94.12)$ & $1(5.88)$ & \\
\hline & ISS > 15 & $126(81.29)$ & $29(18.71)$ & \\
\hline \multicolumn{5}{|l|}{ Seat Position } \\
\hline \multirow[t]{4}{*}{ Driver } & & & & $<0.0001$ \\
\hline & ISS $<9$ & $820(97.16)$ & $24(2.84)$ & \\
\hline & ISS 9-15 & $98(89.91)$ & $11(10.09)$ & \\
\hline & ISS > 15 & $1690(88.95)$ & $210(11.05)$ & \\
\hline \multirow[t]{4}{*}{ Front Passenger } & & & & 0.041 \\
\hline & ISS $<9$ & $261(91.26)$ & $25(8.74)$ & \\
\hline & ISS 9-15 & $41(89.13)$ & $5(10.87)$ & \\
\hline & ISS > 15 & 429 (85.12) & 75 (14.88) & \\
\hline \multirow[t]{4}{*}{ Rear Passenger } & & & & 0.005 \\
\hline & $I S S<9$ & $124(53.68)$ & $107(46.32)$ & \\
\hline & ISS 9-15 & $13(38.24)$ & $21(61.76)$ & \\
\hline & ISS > 15 & $220(41.28)$ & $313(58.72)$ & \\
\hline \multicolumn{5}{|l|}{ Time of Arrival } \\
\hline \multirow[t]{4}{*}{ 0700-0959 h } & & & & $<0.0001$ \\
\hline & ISS $<9$ & $126(92.65)$ & $10(7.35)$ & \\
\hline & ISS 9-15 & $15(75)$ & $5(25)$ & \\
\hline & ISS > 15 & $173(69.2)$ & 77 (30.8) & \\
\hline All other times & & & & $<0.0001$ \\
\hline (1000-1659 h & ISS $<9$ & 1079 (88.08) & 146 (11.92) & \\
\hline 1700-1959 h & ISS 9-15 & 137 (80.59) & $33(19.41)$ & \\
\hline 2000-0659 h) & ISS > 15 & $2229(80.32)$ & 546 (19.68) & \\
\hline
\end{tabular}

\section{Conclusion}

While overall seatbelt compliance in our study is high, efforts can be made to further increase compliance for morning rush hour passengers, rear seat passengers, and occupants of buses, heavy transport vehicles, and vans or pickups. Non-resident vehicle occupants from Malaysia, India, and China have higher seatbelt compliance in Singapore than in studies conducted in their home countries.

\section{Ethics approval and consent to participate}

Ethical approval was given by the first author's (Singapore General Hospital) Institutional Review Board and all data was de-identified and analysed on password-protected 
computers. Consent was not obtained because information was anonymized and de-identified prior to analysis, as per NRDO protocol.

\section{Availability of data and materials}

The data was obtained from a third party, the National Trauma Registry, established by Singapore's Ministry of Health. Data are available from the National Registry of Diseases Office in Singapore for researchers who meet the criteria for access to confidential data. Details are available at https://www.nrdo.gov.sg/data-request/faq.

\section{Abbreviations \\ NRDO: National Registry of Diseases Office; NTR: Singapore National Trauma Registry.}

\section{Competing interests}

The authors declare that they have no competing interests.

\section{Authors' contributions}

THW drafted the initial manuscript. THW, MEHO, KYC, HVN, and HCC developed the research concept. GHL, NNZ, and THW analysed the data. The Trauma Coordinators and Trauma Service Representatives from Changi General Hospital, National University Hospital, Khoo Teck Puat Hospital, Tan Tock Seng Hospital and Singapore General Hospital, Singapore collected the data and contributed to the research concept. All authors contributed to the revision of the paper. All authors read and approved the final manuscript.

\section{Acknowledgements}

The authors would like to thank Dr Tong G On, the National Trauma Committee, the National Trauma Registry working group, Tan Tock Seng Trauma Unit, other trauma database coordinators of the National Trauma Registry, colleagues at the National Registry of Diseases Office for maintaining the NTR, and the National University Hospital Singapore Medical Publications Support Unit for help with the preparation of this manuscript. The following trauma co-ordinators and trauma service representatives from Changi General Hospital, National University Hospital, Khoo Teck Phuat Hospital, Tan Tock Seng Hospital and Singapore General Hospital, Singapore, contributed to this paper:

Haslizah binte Hassan. Changi General Hospital, Singapore Serena Ee Ling, Koh. Changi General Hospital, Singapore Siew Fung, Lim. Changi General Hospital, Singapore Nadhirah binte Sani. Changi General Hospital, Singapore Nurhaida Binte Saad. Changi General Hospital, Singapore Pei Lin, Ng. Changi General Hospital, Singapore Peifu, Ng. Changi General Hospital, Singapore

Chee Keong, Chong. Changi General Hospital, Singapore Sock Teng, Chin. National University Hospital, Singapore Philip Tsau Choong, lau. National University Hospital, Singapore Victor Yeok Kein, Ong. National University Hospital, Singapore Penny Yun Lin, Teo. National University Hospital, Singapore Sabrina Siok Buay, Yeo. National University Hospital, Singapore Woan Wui, Lim. Khoo Teck Puat Hospital, Singapore E Shaun, Goh. Khoo Teck Puat Hospital, Singapore Kenneth Seck Wai, Mak. Khoo Teck Puat Hospital, Singapore Jolene Yu Xuan, Cheng. Tan Tock Seng Hospital, Singapore Ming Terk, Chiu. Tan Tock Seng Hospital, Singapore Karen Tsung Shyen, Go. Tan Tock Seng Hospital, Singapore Ting Ting, Liu. Tan Tock Seng Hospital, Singapore Pei Leng, Chong. Singapore General Hospital, Singapore Norhayati binte Mohamed Jainodin. Singapore General Hospital, Singapore.

\section{Funding}

The authors received no specific individual funding for this work. The collection and management of data for the National Trauma Registry is funded by the Ministry of Health, Singapore.

\section{Author details}

'Department of General Surgery, Singapore General Hospital, Outram Road, Singapore 169608, Singapore. ${ }^{2}$ Health Promotion Board, 3 Second Hospital Ave, Singapore 168937, Singapore. ${ }^{3}$ Department of Emergency Medicine, Singapore General Hospital, Outram Road, Singapore 169608, Singapore. ${ }^{4}$ Duke-National University of Singapore Graduate Medical School, 8 College Rd, Singapore 169857, Singapore. ${ }^{5}$ National University of Singapore, 10 Kent Ridge Crescent, Singapore 119260, Singapore.

Received: 22 January 2016 Accepted: 4 May 2016

Published online: 14 May 2016

\section{References}

1. Vecino-Ortiz A, Bishai D, Chandran A, Bhalla K, Bachani A, Gupta S, Slyunkina E, Hyder A. Seatbelt wearing rates in middle income countries: a cross-country analysis. Accid Anal Prev. 2014;71:115-9.

2. World Health Organization. WHO | Global status report on road safety 2009. 2015.

3. Ozkan T, Puvanachandra P, Lajunen T, Hoe C, Hyder A. The validity of selfreported seatbelt use in a country where levels of use are low. Accid Anal Prev. 2012;47:75-7.

4. Gross E, Axberg A, Mathieson K. Predictors of seatbelt use in American Indian motor vehicle crash trauma victims on and off the reservation. Accid Anal Prev. 2007;39:1001-5.

5. Bogstrand S, Larsson M, Holtan A, Staff T, Vindenes V, Gjerde H. Associations between driving under the influence of alcohol or drugs, speeding and seatbelt use among fatally injured car drivers in Norway. Accid Anal Prev. 2015;78:14-9.

6. Lerner E, Jehle D, Billittier A, Moscati R, Connery C, Stiller G. The influence of demographic factors on seatbelt use by adults injured in motor vehicle crashes. Accid Anal Prev. 2001;33:659-62.

7. El-Menyar A, Consunji R, Asim M, Abdelrahman H, Zarour A, Parchani A, Peralta R, Al-Thani H. Underutilization Of Occupant Restraint Systems In Motor Vehicle Injury Crashes: A Quantitative Analysis From Qatar. Traffic Inj Prev. 2015;13.

8. Department of Statistics Singapore [http://www.singstat.gov.sg/]. Accessed 8 May 2016.

9. Attorney-General's Chambers Singapore: Singapore Statutes Online - 15 Road Traffic (Motor Vehicles, Seat Belts) Rules. 2015.

10. Siviroj P, Peltzer K, Pengpid S, Morarit S. Non-seatbelt use and associated factors among Thai drivers during Songkran festival. BMC Public Health. 2012;12:608.

11. Mohamed N, Mohd Y, Isah N, Othman I, Syed R, Paiman N. Analysis of factors associated with seatbelt wearing among rear passengers in Malaysia. Int J Inj Contr Saf Promot. 2011;18:3-10.

12. $\mathrm{Ng} \mathrm{C}$, Law T, Wong $\mathrm{S}$, Kulanthayan $\mathrm{S}$. Factors related to seatbelt-wearing among rear-seat passengers in Malaysia. Accid Anal Prev. 2013;50:351-60.

13. Passmore J, Ozanne-Smith J. Seatbelt use amongst taxi drivers in Beijing, China. Int J Inj Contr Saf Promot. 2006;13:187-9.

14. Routley V, Ozanne-Smith J, Li D, Hu X, Wang P, Qin Y. Pattern of seat belt wearing in Nanjing, China. Inj Prev J Int Soc Child Adolesc Inj Prev. 2007;13:388-93

15. Routley V, Ozanne-Smith J, Qin Y, Wu M. Taxi driver seat belt wearing in Nanjing, China. J Safety Res. 2009;40:449-54.

16. Stevenson M, Yu J, Hendrie D, Li L, Ivers R, Zhou Y, Su S, Norton R. Reducing the burden of road traffic injury: translating high-income country interventions to middle-income and low-income countries. Inj Prev J Int Soc Child Adolesc Inj Prev. 2008;14:284-9.

17. Kulkarni V, Kanchan T, Palanivel C, Papanna M, Kumar N, Unnikrishnan B. Awareness and practice of road safety measures among undergraduate medical students in a South Indian state. J Forensic Leg Med. 2013;20:226-9.

18. Peltzer K, Pengpid S, Mohan K. Prevalence of health behaviors and their associated factors among a sample of university students in India. Int J Adolesc Med Health. 2014;26:531-40.

19. Sharma R, Grover V, Chaturvedi S. Health-risk behaviors related to road safety among adolescent students. Indian J Med Sci. 2007;61:656-62.

20. Swain S, Mohanan P, Sanah N, Sharma V, Ghosh D. Risk behaviors related to violence and injury among school-going adolescents in Karnataka, Southern India. Int J Adolesc Med Health. 2014;26:551-8.

21. National Registry of Diseases Office S: National Trauma Registry Annual Registry Report 2012-2013. 2014. 
22. Wong T, Nguyen H, Chiu M, Chow K, Ong M, Lim G, Nadkarni N, Bautista D, Cheng J, Loo L, Seow D. The Low Fall as a Surrogate Marker of Frailty Predicts Long-Term Mortality in Older Trauma Patients. PLoS One. 2015;10: 10.

23. Ho A, Chew D, Wong T, Ng Y, Pek P, Lim S, Anantharaman V, Hock O. Prehospital Trauma Care in Singapore. Prehospital Emerg Care Off J Natl Assoc EMS Physicians Natl Assoc State EMS Dir 2014

24. Allen S, Zhu S, Sauter C, Layde P, Hargarten S. A comprehensive statewide analysis of seatbelt non-use with injury and hospital admissions: new data, old problem. Acad Emerg Med Off J Soc Acad Emerg Med. 2006;13:427-34.

25. Mahfoud Z, Cheema S, Alrouh H, Al-Thani M, Al-Thani A, Mamtani R. Seat belt and mobile phone use among vehicle drivers in the city of Doha. Qatar: an observational study BMC Public Health. 2015;15:937.

26. Ichikawa M, Nakahara S, Okubo T, Wakai S. Car seatbelt use during pregnancy in Japan: determinants and policy implications. Inj Prev J Int Soc Child Adolesc Inj Prev. 2003;9:169-72.

27. Jamjute $\mathrm{P}$, Eedarapalli $\mathrm{P}$, Jain $\mathrm{S}$. Awareness of correct use of a seatbelt among pregnant women and health professionals: a multicentric survey. J Obstet Gynaecol J Inst Obstet Gynaecol. 2005;25:550-3.

28. Sirin H, Weiss HB, Sauber-Schatz EK, Dunning K. Seat belt use, counseling and motor-vehicle injury during pregnancy: results from a multi-state population-based survey. Matern Child Health J. 2007;11:505-10.

29. Allen M, Elliott M, Morales L, Diamant A, Hambarsoomian K, Schuster M. Adolescent participation in preventive health behaviors, physical activity, and nutrition: differences across immigrant generations for Asians and Latinos compared with Whites. Am J Public Health. 2007:97:337-43.

30. Singh G, Siahpush M. All-cause and cause-specific mortality of immigrants and native born in the United States. Am J Public Health. 2001;91:392-9.

31. Zambon F, Fedeli U, Marchesan M, Schievano E, Ferro A, Spolaore P. Seat belt use among rear passengers: validity of self-reported versus observational measures. BMC Public Health. 2008:8:233.

32. World Health Organization. WHO | Seat-belts and child restraints: a road safety manual for decision-makers and practitioners. 2009.

\section{Submit your next manuscript to BioMed Central} and we will help you at every step:

- We accept pre-submission inquiries

- Our selector tool helps you to find the most relevant journal

- We provide round the clock customer support

- Convenient online submission

- Thorough peer review

- Inclusion in PubMed and all major indexing services

- Maximum visibility for your research

Submit your manuscript at www.biomedcentral.com/submit
Biomed Central 